\title{
Binding Property of LDH-linked IgG in Serum to Protein A-Sepharose CL-4B*
}

\author{
Yaeko Fujiwara** and Tatsuo Tozawa**
}

\begin{abstract}
Summary
The binding capacity of LDH-linked IgG to Protein A-Sepharose CL-4 B was examined in the sera of 12 patients. Protein $A$ binds to the major part of immunoglobulin $G$ and therefore also to LDH-linked IgG.

Each patient's serum was incubated with Protein A-Sepharose CL-4 B immunosorbent, then $\mathrm{LDH}$ activity in the sediment was measured. $\mathrm{LDH}$ activity on this immunosorbent was demonstrated for every patient, which showed that LDH-linked IgG bound to this immunosorbent.

The method, using Protein A-Sepharose CL-4 B, was simple and quantitative for the detection of LDH-linked $\mathrm{IgG}$, because Protein A reacts to $\mathrm{IgG}$ at a constant rate and one molecule of $\mathrm{LDH}$ linked to one molecule of $\mathrm{IgG}$. Observation of the quantitative dynamics of LDH-linked IgG following the progress of the clinical condition of the disease may be useful to understand the pathophysiological property of LDH-linked IgG.
\end{abstract}

Key words : LDH-linked IgG, Protein A-Sepharose CL-4 B.

\section{Introduction}

Protein A binds to immunoglobulin $G$ (IgG) with the exception of $\operatorname{IgG}_{3}{ }^{1}$. Thus the application of Protein A-Sepharose CL-4 B immunosorbent for the detection of enzyme-linked IgG has been studied. Binding of alkaline phosphatase (ALP)-linked IgG or creatinine phosphokinase(CK)-linked IgG to Protein A-Sepharose CL-4B has been already demonstrated by Kurt Bauer et al. ${ }^{2)}$. However, binding of lactate dehydrogenase ( $\mathrm{LDH}$ )-linked IgG to this immunosorbent had not been investigated until now. The reason why there was no study for the detection of LDH-linked IgG using Protein ASepharose CL-4B is that the number of patients with $\mathrm{LDH}$-linked IgG was $\mathrm{few}^{3}$. A further reason is that the subclass of $\mathrm{LDH}$-linked $\mathrm{IgG}$ reported previously is almost all $\mathrm{IgG}_{3}$. Biewenga found $\mathrm{LDH}$ - linked $\operatorname{IgG}_{3}{ }^{4}$ ) in 13 out of 14 cases of LDH-linked IgG in 1975. Kano ${ }^{5)}$ reported that $\operatorname{IgG}_{3}$ was the main subclass of LDH-linked IgG.

In the present study, we analyzed LDH-linked IgG in the sera of 12 patients and found binding capacity of LDH-linked IgG to Protein A-Sepharose CL-4 B in all of the patients.

\section{Materials and Methods}

Sera were obtained from 12 patients with LDHlinked IgG. The clinical data for these patients and results of the serum analysis are noted in Table 1.

Control sera from two patients did not contain LDH-linked Ig. Control serum 1 was obtained from a 37 year-old male patient with acute hepatitis (LDH activity : 1,282 Wróblewski Unit(W.U.), IgG concentration: $791 \mathrm{mg} / \mathrm{dl}$ ). Control serum 2 was

* LDH 結合性 IgG の Protein A-Sepharose CL-4 B への吸着性.

** 藤原弥栄子, 戸沢辰雄, 兵庫医科大学病院中央検査部.

（受付 1983年1月8日, 受理 1983年4月4日） 
Table 1. Clinical data and results of serum analysis.

\begin{tabular}{|c|c|c|c|c|c|c|}
\hline Patient & Sex & Age & Diagnosis & $\begin{array}{l}\mathrm{LDH} \\
\text { activiiy } \\
\text { (W.U.) }\end{array}$ & $\begin{array}{l}\text { IgG level } \\
(\mathrm{mg} / \mathrm{dl})\end{array}$ & $\begin{array}{l}\text { Light chain* } \\
\text { type of LDH- } \\
\text { linked IgG }\end{array}$ \\
\hline \multicolumn{7}{|l|}{ Group I } \\
\hline $\mathrm{Nt}$ & $\mathrm{m}$ & 46 & Ulcerative Colitis & 353 & 1,500 & $\mathrm{~L}$ \\
\hline $\mathrm{Hk}$ & $\mathrm{m}$ & 68 & Diabetes Mellitus & 890. & 1,800 & $K \& L$ \\
\hline Ms & $\mathrm{m}$ & 49 & Liver Cancer & 247 & 1,038 & $\mathrm{~K} \& \mathrm{~L}$ \\
\hline $\mathrm{Yh}$ & $\mathrm{m}$ & 87 & Pruritus Senilis & 706 & 1,068 & L \\
\hline $\mathrm{Yr}$ & $\mathrm{f}$ & 85 & Cerebral Thrombosis & 293 & 1,136 & $\mathrm{~K}$ \\
\hline $\mathrm{Oh}$ & $\mathrm{m}$ & 20 & Ulcerative Colitis & 257 & 1,700 & $\mathrm{~L}$ \\
\hline \multicolumn{7}{|l|}{ Group II } \\
\hline Iy & $\mathrm{m}$ & 63 & Rheumatism & 650 & 1,655 & $K \& L$ \\
\hline $\mathrm{Ks}_{\mathrm{s}}$ & $\mathrm{m}$ & 71 & $\begin{array}{c}\text { Arteriosclerotic } \\
\text { Obstruction }\end{array}$ & 404 & 1,245 & $\mathrm{~K} \& \mathrm{~L}$ \\
\hline $\mathrm{Ty}_{\mathrm{y}}$ & $\mathrm{m}$ & 54 & Liver Cancer & 520 & 2,205 & $K \& L$ \\
\hline Sk & $\mathrm{f}$ & 42 & Ulcerative Colitis & 429 & 1,280 & $\mathrm{~K}$ \\
\hline \multicolumn{7}{|l|}{ Group III } \\
\hline $\mathrm{Ny}$ & $\mathrm{m}$ & 31 & Ulcerative Colitis & 290 & 1,901 & $\mathrm{~L}$ \\
\hline $\mathrm{Mt}$ & $\mathrm{f}$ & 22 & Ulcerative Colitis & 227 & 1,750 & $\mathrm{~L}$ \\
\hline
\end{tabular}

* K ; Kappa, L ; Lambda

obtained from a 64 year-old female patient with $\mathrm{IgG}_{3}$ multiple myeloma (LDH activity : $162 \mathrm{~W}$. U., IgG concentration : $1900 \mathrm{mg} / \mathrm{dl}$ ).

Measurement of LDH activity : LDH activity was measured by the use of a LDH activity assay kit (LDH NEO D, Eiken Kagaku Co., Ltd, Japan) according to the modified Babson-Phillips method ${ }^{6}$. The substrate solution was made up of $250 \mathrm{mM} \mathrm{D}$, L-lithium lactate.

Assay of LDH isoenzyme : The sera were electrophoretically analyzed on cellulose acetate membrane (TITAN III, Helena Laboratories, U.S. A.)

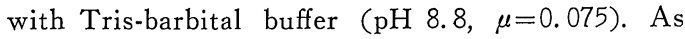
Sepharose beads disturbed LDH isoenzymes causing separation on TITAN III membrane, supernate A was subjected to electrophoresis on polyacrylamide disc gel (containing $7 \%$ acrylamide, $\mathrm{pH}$ 8.9). It was performed for about 1 hour at $3 \mathrm{~mA}$ per tube using Tris-glycine buffer ( $\mathrm{pH}$ 8.9.). LDH isoenzymes were stained with LD Vis Reagent (Helena Laboratories, U.S.A.).

Determination of binding to Protein A-Sepharose $\mathrm{CL}-4 \mathrm{~B}$ : The procedures followed were those of Kurt Bauer et al. ${ }^{2)}$ as shown in Fig. 1. Each patient's serum separated into $500 \mu \mathrm{l}$ was incubated

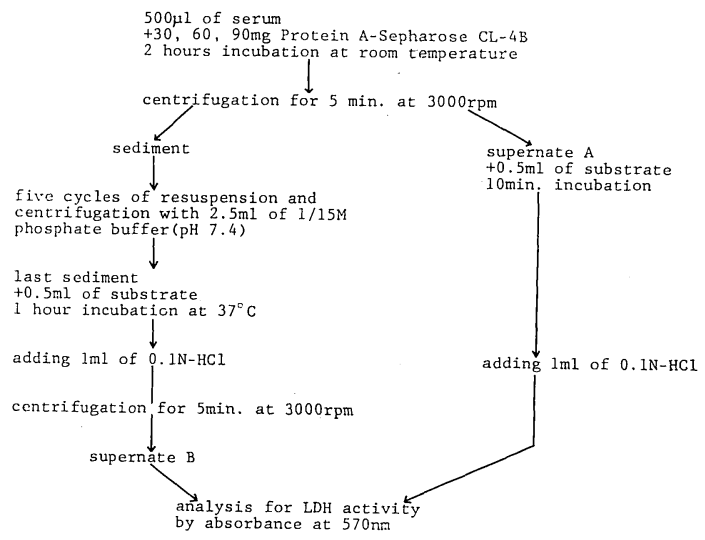

Fig. 1. Schematic diagram for the detection of LDH-linked IgG which binds to Protein A-Sepharose CL-4 B.

with 30, 60 and $90 \mathrm{mg}$ of Protein A-Sepharose CL$4 \mathrm{~B}$ for 2 hours at room temperature. Control serum was also tested at the same time. After removing the supernate from the above mixture by centrifugation ( $5 \mathrm{~min}, 3,000 \mathrm{rpm}$ ), the sediment was washed with $1 / 15 \mathrm{M}$ phosphate buffer ( $\mathrm{pH} 7.4$ ) five times. LDH activity in the first supernate and the last sediment was measured by the method as described above. 
Measurement of IgG concentration : IgG concentration in the serum and in the supernate was measured by single radial immunodiffusion method (HYLAND, U.S.A.).

\section{Results}

LDH-linked IgG was demonstrated in the sera of 12 patients by the method of immunoprecipitin reaction in free liquid media ${ }^{7)}$.

These 12 patients could be divided into 3 groups according to differences in the $\mathrm{LDH}$ isoenzyme patterns on TITAN III membrane. In group I, $\mathrm{LDH}_{1}, \mathrm{LDH}_{2}, \quad \mathrm{LDH}_{3}$ and $\mathrm{LDH}_{4}$ bands diffused toward the cathode side. As $\mathrm{LDH}_{5}$ band migrated more anodically, a fraction of $\mathrm{LDH}_{4}$ overlapped with a fraction of $\mathrm{LDH}_{5}$ and there seemed to occur an abnormal $\mathrm{LDH}$ band between the usual $\mathrm{LDH}_{4}$ and $\mathrm{LDH}_{5}$ bands. The LDH isoenzyme pattern in the serum of patient $\mathrm{Oh}$ did not show clear abnormality on TITAN III membrane. But on polyacrylamide disc gel, it showed an extra $\mathrm{LDH}$ band just to the anode side of the $\mathrm{LDH}_{5}$ band. In group II, each $\mathrm{LDH}$ fraction was very diffuse and migrated more cathodically. In patient Iy, the zymogram of $\mathrm{LDH}$ was extremely unusual. It seemed to be composed of one major band between $\mathrm{LDH}_{4}$ and $\mathrm{LDH}_{5}$ zones. In group III, the activity of $\mathrm{LDH}_{4}$ and $\mathrm{LDH}_{5}$ was characteristically low. The diffuse patterns of three bands, $\mathrm{LDH}_{1}, \mathrm{LDH}_{2}$ and $\mathrm{LDH}_{3}$, were the same as those of group I.

Results of binding capacity of LDH-linked IgG to Protein A-Sepharose CL-4 B are summarized in Table 2. LDH activity is shown by an optical density at $570 \mathrm{~nm}$. The individual results are shown by graphs in Fig. 2-a and $-b$.

Results of patients in group $I$ are shown in Fig. 2-a. By addition of $90 \mathrm{mg}$ of Protein A-Sepharose $\mathrm{CL}-4 \mathrm{~B}, \mathrm{LDH}$ activity in the supernate decreased to about $60 \%$ of total serum LDH activity (graph A). LDH activity on $30 \mathrm{mg}$ of Protein A: Sepharose CL-4 B was equal to an optical density of 0.035 to 0.090 (graph B). Results of other patients are shown in Fig. 2-b. In group II, LDH activity in the supernate decreased to about $50 \%$ of
Table 2. Optical density at $570 \mathrm{~nm}$ of the supernate (A) and the sediment(B). $\mathrm{LDH}$ activity in the sediment of the control was below 0.002 (optical density).

\begin{tabular}{|c|c|c|c|c|c|}
\hline \multirow{3}{*}{ Patient } & \multicolumn{4}{|c|}{ LDH activity (O.D. at $570 \mathrm{~nm}$ ) } & \\
\hline & \multirow{2}{*}{ Serum } & \multicolumn{3}{|c|}{$\begin{array}{l}\text { After adding Protein A- } \\
\text { Sepharose CL-4 B (mg) }\end{array}$} & \\
\hline & & 30 & 60 & 90 & \\
\hline \multicolumn{6}{|l|}{ Group I } \\
\hline \multirow[t]{2}{*}{$\mathrm{Nt}$} & 0.309 & 0.243 & 0.210 & 0.181 & A \\
\hline & & 0.051 & 0.086 & 0.162 & $\mathrm{~B}$ \\
\hline \multirow[t]{2}{*}{$\mathrm{Hk}$} & 0.639 & 0.548 & 0.526 & 0.424 & $\mathrm{~A}$ \\
\hline & & 0.090 & 0.165 & 0.202 & $\mathrm{~B}$ \\
\hline \multirow[t]{2}{*}{ Ms } & 0.179 & 0.168 & 0.155 & 0.103 & $\mathrm{~A}$ \\
\hline & & 0.089 & 0.199 & 0.230 & $\mathrm{~B}$ \\
\hline \multirow[t]{2}{*}{$\mathrm{Yh}$} & 0.559 & 0.519 & 0.398 & 0.321 & A \\
\hline & & 0.088 & 0.162 & 0.184 & $\mathrm{~B}$ \\
\hline \multirow[t]{2}{*}{ Yr } & 0.208 & 0.188 & 0.153 & 0.114 & $\mathrm{~A}$ \\
\hline & & 0.043 & 0.073 & 0.122 & B \\
\hline \multirow[t]{2}{*}{$\mathrm{Oh}$} & 0.174 & 0.167 & 0.139 & 0.088 & A \\
\hline & & 0.035 & 0.079 & 0.111 & B \\
\hline
\end{tabular}

Group II

\begin{tabular}{|c|c|c|c|c|c|}
\hline Iy & 0.507 & 0.461 & 0.326 & 0.198 & A \\
\hline & & 0.406 & 0.536 & 0.596 & B \\
\hline $\mathrm{Ks}$ & 0.315 & 0.271 & 0.228 & 0.183 & A \\
\hline & & 0.234 & 0.273 & 0.347 & $B$ \\
\hline Ty & 0.362 & 0.311 & 0.219 & 0.167 & A \\
\hline & & 0.151 & 0.224 & 0.291 & B \\
\hline Sk & 0.313 & 0.280 & 0.178 & 0.149 & A \\
\hline & & 0.103 & 0.260 & 0.264 & \\
\hline
\end{tabular}

Group III

\begin{tabular}{l|l|l|l|l|l}
$\mathrm{Ny}$ & 0.195 & 0.193 & 0.191 & 0.175 & $\mathrm{~A}$ \\
$\mathrm{Mt}$ & 0.130 & 0.032 & 0.041 & 0.053 & $\mathrm{~B}$ \\
& & 0.121 & 0.117 & 0.111 & $\mathrm{~A}$ \\
& & 0.015 & 0.028 & 0.034 & $\mathrm{~B}$
\end{tabular}

serum activity. $\mathrm{LDH}$ activity on $30 \mathrm{mg}$ of Protein A-Sepharose CL-4 B was very high. It was equal to an optical density of 0.103 to 0.406 . That indi: cated a large amount of LDH-linked IgG. In group III, LDH activity in the sediment was low and the slope of the increasing line (graph B) was very gentle. There seemed to be little LDH-linked IgG.

In every case, IgG in the patient's serum binds to Protein A-Sepharose CL-4 B reliably: Addition of $90 \mathrm{mg}$ of Protein A-Sepharose CL-4 B caused a 


\section{Group I}
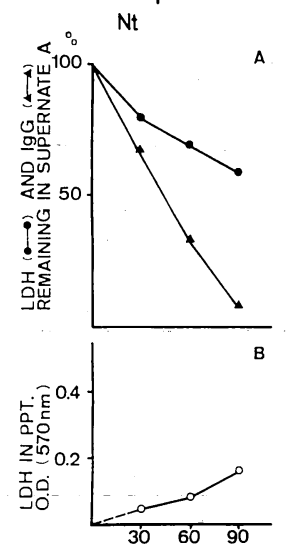

PROTEIN A-SEPHAROSE CL-4B / $500 \mu$ I SERUM

$\mathrm{Yr}$

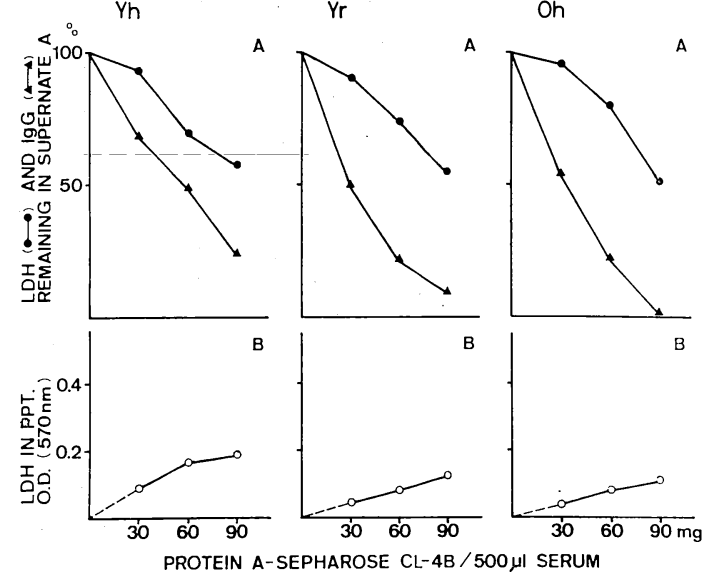

Fig. 2-a. LDH activity in the supernate (graph A) and in the sediment (graph B) of Group I as amount of Protein A-Sepharose CL-4 B is increased. Graph A shows percentage of $\mathrm{LDH}$ activity and $\mathrm{IgG}$ concentration remaining in the supernate.

greater than $60 \%$ IgG absorption.

Results of experiments with two kinds of control serum are shown in Fig. 3. IgG concentration in the control serum 1 supernate was decreased by addition of increasing amounts of Protein A-Sepharose CL- $4 \mathrm{~B}$, while LDH activity varied little in the supernate and was not found in the sediment. Therefore, high level of LDH activity had no effect on the measurement of LDH activity on IgG bound Protein A-Sepharose CL-4 B. In the control serum 2 supernate, addition of increasing amounts

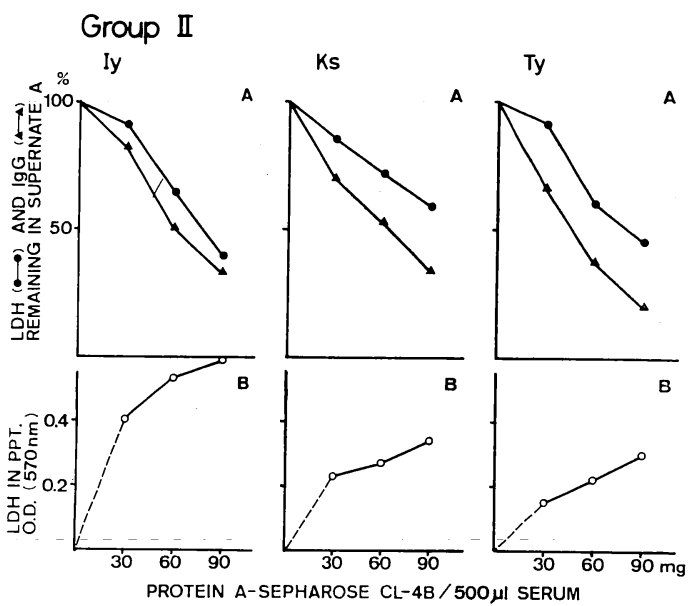

Group II

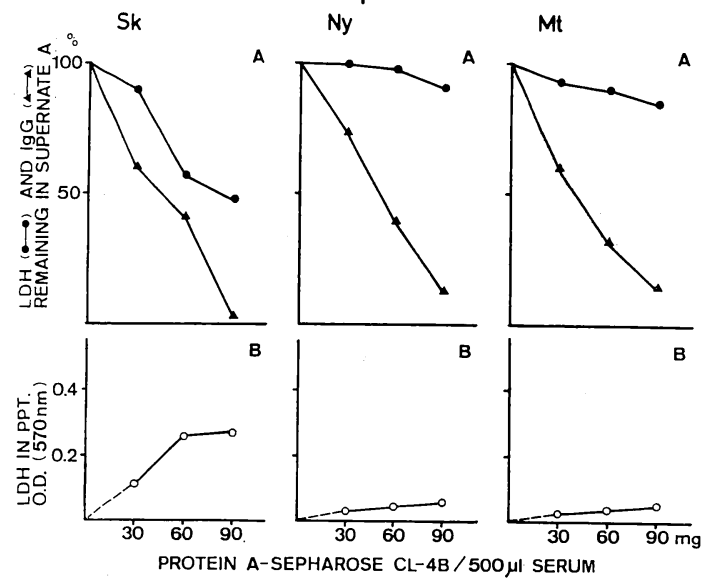

Fig. 2-b. LDH activity in the supernate and in the sediment of Group II and Group III as amount of Protein A-Sepharose CL-4 B is increased.

of Protein A-Sepharose CL-4 B had practically no effect on both IgG concentration and LDH activity. This is because Protein A does not bind to $\mathrm{IgG}_{3}$. There was no LDH activity in the sediment either.

Each supernate was additionally submitted to polyacrylamide disc electrophoresis. LDH isoenzyme pattern of the control serum supernate did not change by addition of increasing amounts of Protein A-Sepharose CL-4 B, whereas, due to the same increase, an abnormal LDH band in every. patient's serum was decreased or caused to disappear and become similar to the normal pattern. 


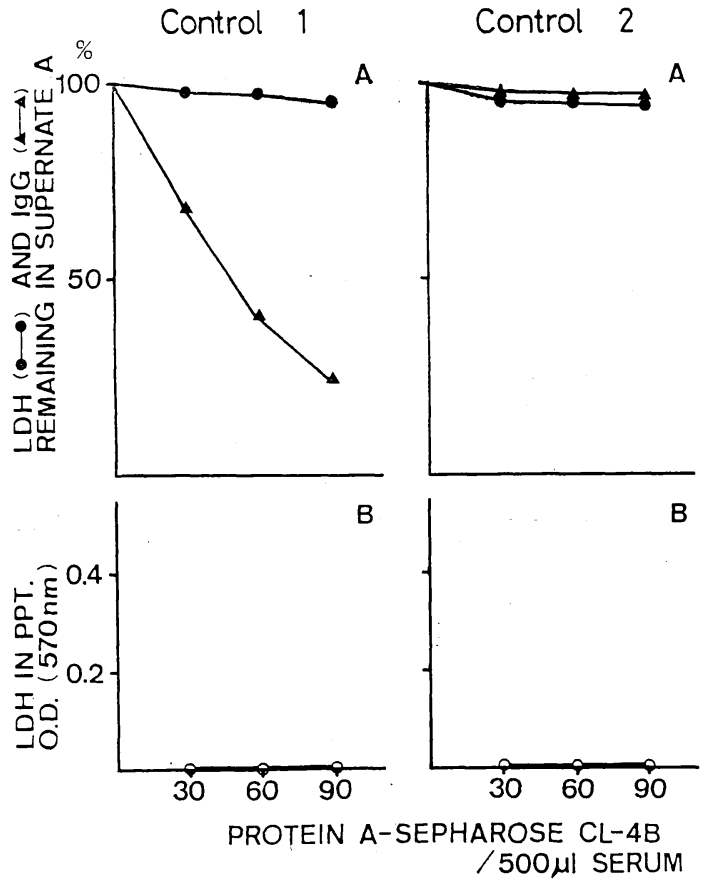

Fig. 3. LDH activity in the supernate and in the sediment of control serum. Control serum 1 was from the patient with high $\mathrm{LDH}$ activity. Control serum 2 was from the patient with $\operatorname{IgG}_{3}$ multiple myeloma.

\section{Discussion}

Since Ganrot $^{8)}$ reported about the patient suffering from lupoid cirrhosis with LDH-linked Ig, the relationship between LDH-linked Ig and autoimmune disease has been suspected. Until now, there had been no close relation found between $\mathrm{LDH}$ linked Ig and any disease. In 1981, G.G. Leroux et al. ${ }^{9)}$ found $\mathrm{LDH}$-linked $\mathrm{Ig}$ in 2 out of 20 patients with ulcerative colitis. We also found ${ }^{10)} \mathrm{LDH}$-linked Ig in 4 out of 42 patients with ulcerative colitis and detected the isotype specificity of LDH-linked Ig in these patients, that being IgG-lambda. Consequently, we were further interested in the occurrence of LDH-linked IgG as an autoimmune complex. Nagamine ${ }^{3)}$ reported that LDH-linked IgG appeared transiently in hepatic disease. ALP-linked IgG appears or disappears according to changes in the clinical condition of ulcerative colitis. Therefore the quantitative variations in LDH-linked IgG must be observed in detail 'following the progression of the disease. Such observation is necessary for the investigation of the nature of LDH-linked IgG.

In this paper, the binding property of $\mathrm{LDH}$ linked IgG to Protein A-Sepharose CL-4 B was demonstrated in all 12 patients, having various diseases. Such a binding property had been also demonstrated in one patient with ALP-linked IgG and one patient with CK-linked IgG by Kurt Bauer et al.2). At present, the most sensitive method of detecting LDH-linked IgG is based on immunoprecipitin reaction in free liquid media. The same sensitivity was obtained by using Protein A-Sepharose CL-4 B. Moreover, LDH-linked IgG could be observed quantitatively from LDH activity on Protein A-Sepharose CL-4 B and also from the reduction of $\mathrm{LDH}$ activity in the supernate as IgG concentration was decreased. The measurement of $\mathrm{LDH}$ activity in the sediment is particularly reliable for the quantitative detection of LDH-linked IgG. This is because Protein A reacts with IgG at a constant rate (IgG $25 \mathrm{mg}$ / Protein A-Sepharose CL-4 B gel $1 \mathrm{ml}$ ) and one molecule of $\mathrm{LDH}$ binds to one molecule of $\mathrm{IgG}^{12)}$. Therefore $\mathrm{LDH}$ activity in the sediment should give approximately a linear increase. A little curve in graph B seemed to be caused by an experimental error. When IgG concentration remaining in the supernate was below $10 \%$ of the serum, Protein A-Sepharose CL-4 B bound to all IgG except $\operatorname{IgG}_{3}$. At this state, $\mathrm{LDH}$ activity in the sediment should show the activity of $\mathrm{LDH}$ bound to IgG. When the remarkable abnormality of $\mathrm{LDH}$ isoenzyme pattern was observed, as in group II, LDH activity in the sediment was very high. On the other hand, when there was a little abnormality, as in group III, LDH activity in the sediment was low and the slope was gentle.

Biewenga et al. ${ }^{4}$ found 13 patients with $\mathrm{LDH}$ linked $\mathrm{IgG}_{3}$ out of 14 with LDH-linked IgG, while $\mathrm{Kano}^{5)}$ reported the predominance of the $\mathrm{IgG}_{3}$ subclass in LDH-linked IgG. The reason, why the binding property of LDH-linked IgG to Protein ASepharose CL-4 B was not investigated, seemed to 
be these reports. However, LDH-linked IgG in all of our 12 patients had the property of binding to Protein A-Sepharose CL-4 B. If Protein A does not bind to $\mathrm{IgG}_{3}$, the $\mathrm{LDH}$-linked IgG in our patients might not be $\mathrm{IgG}_{3}$.

Recently, Ito et al. ${ }^{13}$ ) reported that $\operatorname{IgG}_{3}$ carrying different set of $\mathrm{Gm}$ allotypes had the property of binding to Protein A-Sepharose CL-4 B. Shimizu et al. ${ }^{14)}$ also reported the case of $\mathrm{IgG}_{3}$ myeloma protein binding to Protein A-Sepharose CL-4 B. If the subclass of LDH-linked IgG in all of our patients was $\operatorname{IgG}_{3}$, it might well be $\operatorname{IgG}_{3}$ carrying peculiar Gm allotypes, which can react with Protein A.

Regarding the subclass of $\mathrm{LDH}$-linked IgG, further experiments using antisera of the IgG subclass are necessary. We intend to make that our subject for continuing research.

\section{Acknowledgments}

The authors are very grateful to $\mathrm{Mr}$. H. Shibata, Mr- K. Taishi and Miss J. Kuwahara for their skillful technical assistance.

\section{References}

1) Kronvall, G., and Williams, R.C. : J. Immunol,, $103: 828,1969$.

2) Kurt, B. et al. : Clin. Chem., $26: 297,1980$.

3) Nagamine, M. : Physico-Chem. Biol. (Seibutsubutsurikagaku), 21 : 193, 1977.

4) Biewenga, J. and Feltkamp, T. E. W. : Clin. Chem. Acta, 64 : 101, 1975.

5) Kano, S. : Physico-Chem. Biol. (Seibutsubutsurikagaku), $21: 201,1977$.
6) Babson, A.L. and Phillips, G.E. : Clin. Chem. Acta, $12: 210,1965$.

7) Tozawa, T. et al. : Physico-Chem. Biol. (Seibutsubutsurikagaku), $26: 243,1982$.

8) Ganrot, P.O. : Experimentia, $23: 593,1967$.

9) Leroux-Roels, G.G. et al. : J. Lab. Clin. Med., $97: 316,1981$.

10) Tozawa, T. and Fujiwara, Y. : Physico-Chem. Biol. (Seibutsubutsurikagaku), $26: 79,1982$.

11) Miki, K. et al. : Jpn. J. Gastroenterol. (Nisshōbyōkaishi), $73:$ 162, 1975.

12) Kuwa, K. et al.: Physico-Chem. Biol. (Seibutsubutsurikagaku), $21:$ 209, 1977.

13) Ito, S. et al. : Proc. Japan Acad., 56 : 226, 1980.

14) Shimizu, A. et al. : Jap. J. Clin. Path. (Rinshōbyōri), $29: 123,1981$.

\section{要 旨}

LDH 結合 IgG の Protein A-Sepharose CL-4 B に対する吸着能を，12 例の患者血清で調べた。

患者血清を Protein A-Sepharose CL-4 B とインキ ュベートし，その沈殿物中の $\mathrm{LDH}$ 活性を測定した. その結果, 全例に, Protein A-Sepharose CL-4 B 中 の $\mathrm{LDH}$ 活性が認められ，12 例すべての LDH 結合 IgG が Protein A-Sepharose CL-4 B への吸着性を もつことが示された.

Protein A-Sepharose CL-4B を用いた LDH 結合 $\mathrm{IgG}$ の検出は簡便で，検出感度もすぐれている. しか も, IgG は Protein A と一定の割合で結合し, LDH 1 分子が IgG 1 分子と結合していることから, LDH 結合 IgG を定量的に把握しらる. この方法を用い, LDH 結合 IgG の臨床経過に関連した動態を定量的 に観察することは，この複合物の病態生理学的な解明 に役立つものと期待できる. 